Journal of Bangladesh Academy of Sciences, Vol. 38, No. 2, 177-187, 2014

\title{
SYNTHESIS, CHARACTERIZATION AND ELECTROCHEMICAL STUDIES OF FERROCENYL-2, 4-DINITROPHENYLHYDRAZONE
}

TAHMINA SULTANA, CHOWDHURY A. WAHEED, S. M. SAIFUL ISLAM, ABU ALI IBN SINA, MUHAMMAD YOUNUS ${ }^{*}$, MD. ABDUL JABBAR ${ }^{1}$ AND MD. RIAD HOSSAIN SABUJ ${ }^{1}$

Department of Chemistry, Shahjalal University of Science \& Technology, Sylhet-3114, Bangladesh

\begin{abstract}
A ferrocenyl imine complex, $\mathrm{Fc}-\mathrm{C}\left(\mathrm{CH}_{3}\right)=\mathrm{N}-\mathrm{NH}-\mathrm{C}_{6} \mathrm{H}_{3}-2,4-\left(\mathrm{NO}_{2}\right)_{2}(\mathrm{Fc}=$ ferrocenyl $)$ has been synthesized by the condensation reaction between acetylferrocene and 2,4-dinitrophenyl hydrazine. The compound was synthesised previously, and characterized by IR, ${ }^{1} \mathrm{H}$ and elemental analysis. It was further characterized by ${ }^{13} \mathrm{C}\left\{{ }^{1} \mathrm{H}\right\}$ NMR spectroscopy and mass spectrometry. The redox property of the complex was studied by cyclic voltammetry, differential pulse voltammetry and chronocoulometry. The redox process of the complex was found to be reversible at a platinum-disc electrode, and the redox potential of the imine complex was shifted to more anodic position with respect to ferrocene. The redox reactivity of the complex was enhanced in the presence of oxygen.
\end{abstract}

Key words: Synthesis, Ferrocenenyl imine, Characterization, Electrochemical

\section{INTRODUCTION}

In recent years, bioorganometallic chemistry has become one of the leading areas in organometallic chemistry and biology (Elzaher et al. 2006). Bioorganometallic medicinal chemistry has opened up new areas for studying new meltallodrug molecules (Elzaher et al. 2007) having excellent biological activity (Elzaher et al. 2006). Ferrocenyl Shiffbases are condensation products of arylamines and carbonyl compounds. Compared to the other aromatic imine (Batterjee et al. 2003) these compounds are quite stable and versatile materials for studying biological activity (Trivedi et al. 2012, Chohan and Supuran 2005). These compounds also have extensive applications in homogeneous catalysis, material science, non linear optics and molecular sensor for their air stability and good donor abilities. The presence of heterodonating atoms (such as nitrogen, phosphorus, oxygen, sulphur, etc.) or unsaturated fragment in these materials provides potential site susceptible to which one or more metal ion to be bonded (Sarhan et al. 2003, Xu et al. 2009).

\footnotetext{
${ }^{*}$ Corresponding author:<myounus-che@ sust.edu>.

${ }^{1}$ Department of Chemistry, University of Dhaka, Dhaka-1000, Bangladesh.
} 
The redox property of ferrocene has played a vital role in the synthesis of several functionalized ferrocene derivatives. When a coordination compound is formed, the HOMO energy level changes due to the attraction of ion and ligand (Sarhan et al. 2003). Ferrocene is readily converted into ferricenium ion $\left(\mathrm{Fc}^{+}\right)$through one electron redox couple, and substituent on the ferrocene moiety influences the redox behaviour (Xu et al. 2009). The electron transfer ability makes its derivative good candidates for their investigation in biological applications.

In this paper, the synthesis, characterization, electrochemical properties and biological studies of a ferrocenyl hydrazone complex is reported. The electronic effect in ferrocene moiety upon introduction of an electron withdrawing group is discussed.

\section{MATERIALS AND METHODS}

Acetylferrocene and 2,4 dinitrophenylhydrazine were obtained from Merck Germany. Dichloromethane, methanol, ethanol, ethyl acetate, n-hexane were obtained from Merck Germany and were freshly dried using standard method (Errington 1997). The elemental analysis was performed using a Analyzer System Vario EL III Element Analyzer. Melting points were recorded on a Gallencamp melting-point apparatus and are uncorrected. The solid state Fourier transform infrared spectra were recorded on $\mathrm{KBr}$

plates with an Shimadzu prestige 21 FTIR spectrometer. ${ }^{1} \mathrm{H}$ and ${ }^{13} \mathrm{C}-\mathrm{NMR}$ spectra were obtained on Bruker $400 \mathrm{MHz}$ spectrometer in $\mathrm{CDCl}_{3}$ using tetramethyl silane as internal reference. MS spectra were obtained using Ab sciex LCMSMS (Model 4000 QTRAP).

Synthesis of ferrocenyl-2, 4-dinitrophenylhydrazone $\left(\mathrm{C}_{18} \mathrm{H}_{16} \mathrm{FeN}_{4} \mathrm{O}_{4}\right)$ : The complex was synthesised by the adaption of the literature route (Lopez et al. 1997). 2,4Dinitrophenyl hydrazine $(0.44 \mathrm{~g}, 2.19 \mathrm{mmol})$ was dissolved in the mixture of ethanol $(2 \mathrm{ml}), \mathrm{H}_{2} \mathrm{SO}_{4}(0.3 \mathrm{ml})$ and water $(3 \mathrm{ml})$. Acetyl ferrocene $(0.5 \mathrm{~g}, 2.19 \mathrm{mmol})$ was dissolved in reagent grade ethanol. The hydrazine solution was poured into acetylferrocene solution drop wise. The resulting mixture was stirred for $3 \mathrm{hrs}$ at room temperature during which time a precipitate was appeared. The precipitate was filtered and washed with ethanol and then with n-hexane. The crude product was subjected to silica column chromatography using a $\mathrm{CH}_{2} \mathrm{Cl}_{2} / \mathrm{n}$-hexane (3:2) solvent system. Two bands were eluted, one was identified to be unreacted starting material and another was the desired product. The pure product was obtained as dark brown solid in $69 \%$ yield. Mp.: $187-190^{\circ} \mathrm{C} . \mathbb{R}\left(v_{\max } / \mathrm{cm}^{-1}\right):(\mathrm{C}=\mathrm{C}) 1616,\left(\mathrm{NO}_{2}\right) 1510,1340,(\mathrm{C}=\mathrm{N}) 1595,(\mathrm{~N}-\mathrm{H})$ 3320; ${ }^{1} \mathrm{H}$ NMR $\left(\mathrm{CDCl}_{3}, \delta \mathrm{ppm}\right): 4.2$ (bs, 5H, unsubst. $\mathrm{Cp}$ ), 4.72 (bs, $2 \mathrm{H}, \mathrm{H}_{\mathrm{a}}$ subst. $\mathrm{Cp}$ ), 4.47 (bs, 4H, $\mathrm{H}_{\mathrm{b}}$ subst. Cp), 2.33 (s, 3H, $\mathrm{CH}_{3}$ ), 8.31 (bs, $\left.1 \mathrm{H}, \mathrm{H}_{1}, \mathrm{Ph}\right) 8.0$ (bs, $1 \mathrm{H}, \mathrm{H}_{2}, \mathrm{Ph}$ ), 7.26 (bs, $\left.1 \mathrm{H}, \mathrm{H}_{3}, \mathrm{Ph}\right), 9.15$ (s, $\left.1 \mathrm{H}, \mathrm{N}-\mathrm{H}\right) ;{ }^{13} \mathrm{C} \mathrm{NMR}\left(\mathrm{CDCl}_{3}, \delta \mathrm{ppm}\right): 69.66$ (5C, unsubst. Cp), $71.02\left(2 \mathrm{C}, \mathrm{C}_{\mathrm{a}}\right.$, subst. Cp), $67.52\left(2 \mathrm{C}, \mathrm{C}_{\mathrm{b}}\right.$, subst. Cp), $82.38\left(1 \mathrm{C}, \mathrm{C}_{\mathrm{ipso}}\right.$, subst. Cp), 
$155.10(1 \mathrm{C}, \mathrm{C}=\mathrm{N}), 14.82\left(1 \mathrm{C}, \mathrm{CH}_{3}\right), 144.71\left(1 \mathrm{C}, \mathrm{C}_{1}, \mathrm{Ph}\right), 137.78\left(1 \mathrm{C}, \mathrm{C}_{2}, \mathrm{Ph}\right), 116.80$ $\left(1 \mathrm{C}, \mathrm{C}_{3}, \mathrm{Ph}\right), 130.10\left(1 \mathrm{C}, \mathrm{C}_{4}, \mathrm{Ph}\right), 123.811 \mathrm{C},\left(\mathrm{C}_{5}, \mathrm{Ph}\right), 129.17\left(1 \mathrm{C}, \mathrm{C}_{6}, \mathrm{Ph}\right)$.

Electrochemistry: The cyclic voltammetric responses were recorded using HQ-2040 (Advanced analytics, USA) at the Department of Chemistry, Dhaka University. Measurement was carried out using a standard three-electrode system (Platinum-disc working and platinum-wire auxiliary electrodes and $\mathrm{Ag} / \mathrm{AgCl}$ reference electrode). All of the electrochemical experiments were measured at $298 \mathrm{~K}$ using $0.1 \mathrm{M}\left[\mathrm{Bu}_{4} \mathrm{~N}\right]\left[\mathrm{BF}_{4}\right]$ supporting electrolyte in dichloromethane $\left(\mathrm{CH}_{2} \mathrm{Cl}_{2}\right) \cdot \mathrm{CH}_{2} \mathrm{Cl}_{2}$ was dried on $\mathrm{KOH}$ prior to use of the electrochemical measurement. All of the solutions were $\mathrm{N}_{2}$-purged. The analyte concentration was $1 \times 10^{-4} \mathrm{M}$ in each case.

\section{BIOLOGICAL STUDIES}

Antibacterial assay: Schiff base complex was tested for their antibacterial activity. Antibacterial activity was studied against four bacteria: S. aureus, E. coli, Pseudomonas and Klebsiella. The agar well diffusion method was used for determination of inhibition zone. A single colony from each bacterial culture plate was transferred to nutrient broth (pH 7) and incubated at $37^{\circ} \mathrm{C}$ for $24 \mathrm{hrs}$. Concentrations of the compound was $1 \mathrm{mg} / \mathrm{ml}$. Plates were incubated at $37^{\circ} \mathrm{C}$ aerobically and the zone of inhibition was measured after $24 \mathrm{hrs}$ Experiments were run in triplicate (Trivedi et al. 2012).

\section{RESULTS AND DISCUSSION}

A ferrocenyl imine complex, Fc-C $\left(\mathrm{CH}_{3}\right)=\mathrm{N}-\mathrm{NH}-\mathrm{C}_{6} \mathrm{H}_{4}-2,4-\left(\mathrm{NO}_{2}\right)_{2}(\mathrm{Fc}=$ ferrocenyl $)$ was prepared by the condensation reaction between acetylferrocene and 2,4 dinitrophenyl hydrazine at room temperature (Scheme 1) (Lopez et al. 1997).

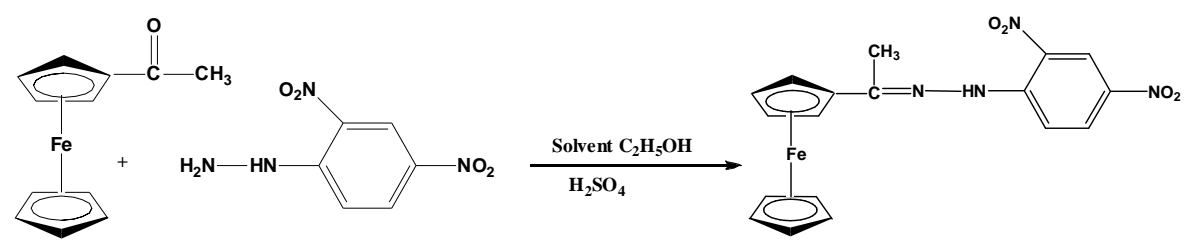

Scheme 1. Preparation of ferrocenyl-2,4-dinitrophenylhydrazone.

The crude product was purified by silica column chromatography using a $3: 2$ mixture of $\mathrm{CH}_{2} \mathrm{Cl}_{2}$ and hexane as eluent. The compound is soluble in methanol, ethanol, dichloromethane, ethyl acetate. The FT-IR and ${ }^{1} \mathrm{H}$ NMR spectroscopic data are consistent with the previously reported data (Lopez et al. 1997).

In the ${ }^{13} \mathrm{C}$ NMR spectrum of the complex (Fig. 1), the deshielded azomethine carbon observed at $155.1 \mathrm{ppm}$. The signal at $14.2 \mathrm{ppm}$ is attributed to the methyl carbon. The 
phenyl carbons displayed their signals at 116.8, 123.8, 129.1, 130.1, 137.7 and 144.7 ppm. Carbon atoms of the ferrocenyl moiety appeared at 67.5, 69.6, 71 and $82.3 \mathrm{ppm}$.

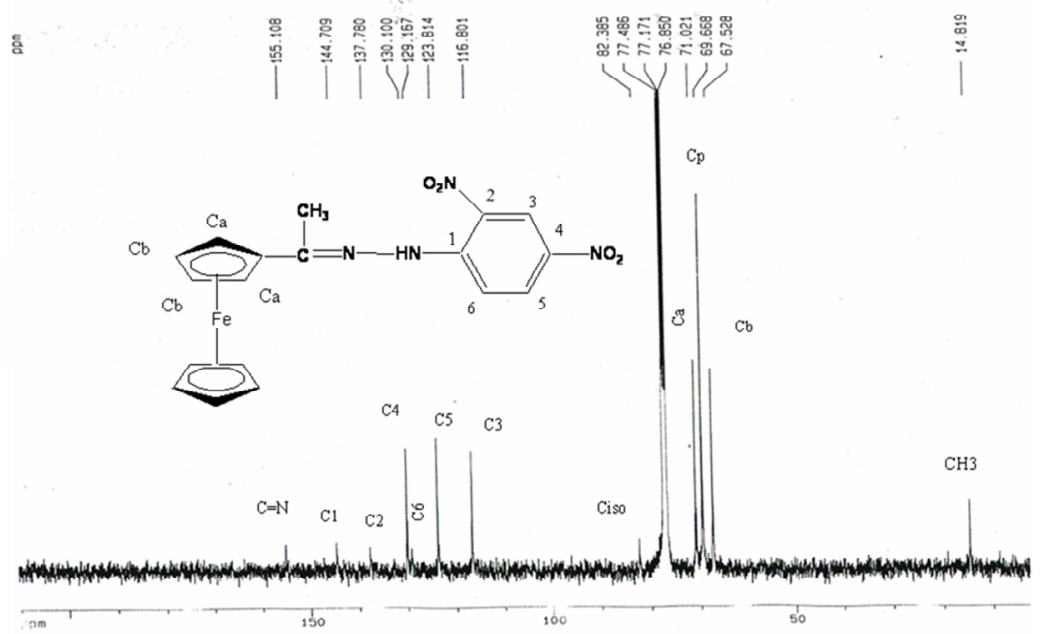

Fig. 1. ${ }^{13} \mathrm{C}$ NMR spectrum of ferrocenyl-2,4-dinitrophenylhydrazone.

The molecular formula of the complex was established by the intense molecular ion peak at $m / z, 408[\mathrm{M}]^{+}$; and their fragmented species in mass spectrum (Fig. 2).

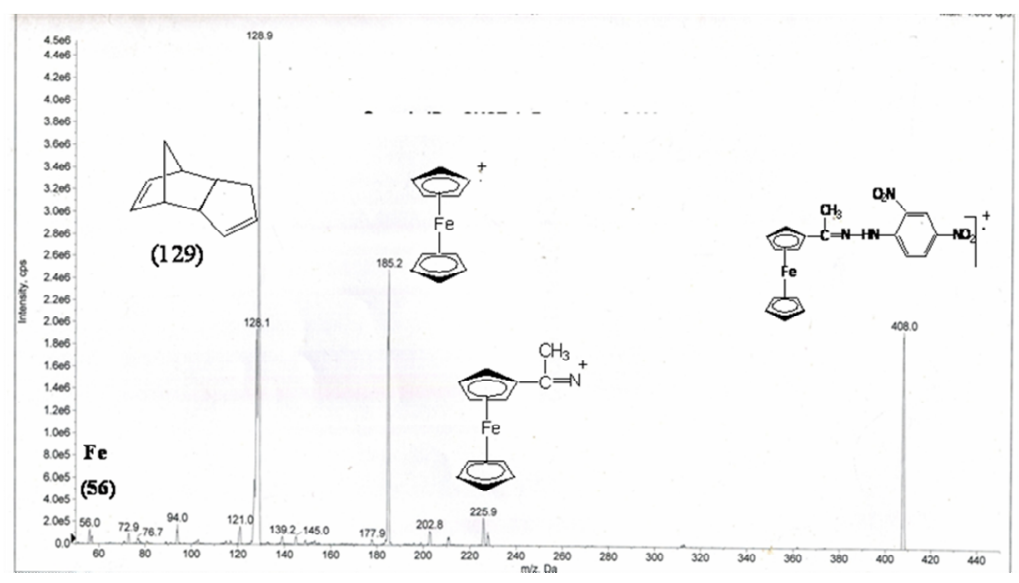

Fig. 2. ESI-MS spectrum of ferrocenyl-2,4-dinitrophenylhydrazone.

Cyclic voltammetry: The redox behaviour of the complex on platinum $(\mathrm{Pt})$-disc electrode was studied in $\mathrm{CH}_{2} \mathrm{Cl}_{2}$ at $25^{\circ} \mathrm{C}$. For this purpose, the cyclic voltammograms of the complex and ferrocene were taken separately with a Pt-disc electrode at a scan rate $50 \mathrm{mV} / \mathrm{s}$ and is shown in Fig. 3. The potential is scanned between 400 and $1200 \mathrm{mV}$. When the potential is sufficiently positive to oxidize $\mathrm{Fe}^{2+}$, anodic current start rising due 
to the oxidation process $-\mathrm{Fe}^{2+} \rightarrow \mathrm{Fe}^{3+}+\mathrm{e}$. As the potential increases and reaches to the $1200 \mathrm{mV}$, the complex of +2 oxidation state converted to +3 .

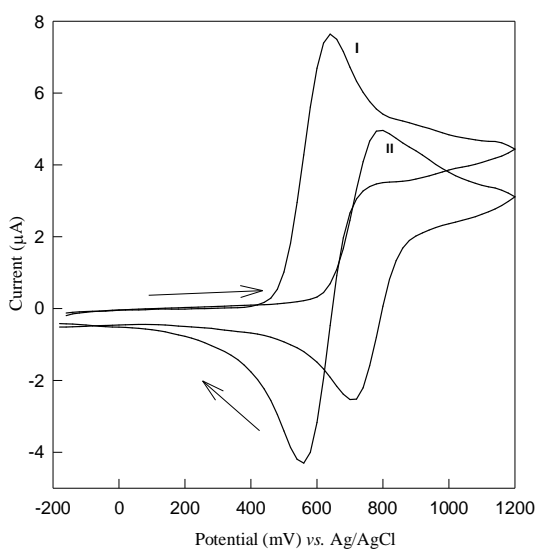

Fig. 3. Cyclic voltammograms of ferrocene (I) and the compound (II) in $\mathrm{CH}_{2} \mathrm{Cl}_{2}$ containing $0.1 \mathrm{M}\left[\mathrm{Bu}_{4} \mathrm{~N}\right]\left[\mathrm{BF}_{4}\right]$ solution; scan rate $50 \mathrm{mV} / \mathrm{sec}$.

The current then decays as there is no more complex (at +2 oxidation state) present surrounding the electrode. When the potential reaches to $1200 \mathrm{mV}$, reverse scanning is started, and reduction of the complex at +3 oxidation state of $\mathrm{Fe}$ starts resulting the rising of cathodic current in the opposite direction. As the potential decreases and reaches the reduction potential of the complex the current reaches a peak. At this point the entire complex at +3 oxidation states has been converted to +2 oxidation states [Sarhan et al. 2003].

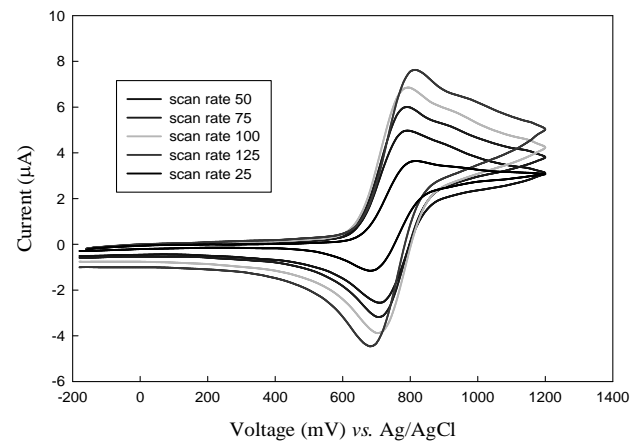

Fig. 4. Cyclic voltammogram of ferrocenyl-2,4-dinitrophenylhydrazone complex at various scan rate.

The cyclic voltammetric behaviour of the compound was studied at various scan rates (Fig. 4) at a potential range $-0.2-1.4 \mathrm{~V}$. The voltammogram showed a pair of robust redox waves. 
The voltammetric response is attributed to the one electron redox process of the $\mathrm{Fe}^{2+} / \mathrm{Fe}^{3+}$ couple and Table 1 reflects the reversibility of the redox process as the pick potentials are not significantly affected by the variation of scan rates. The redox process also follows the conditions of reversibility.

(i) $\mathrm{i}_{\mathrm{pa}} / \mathrm{i}_{\mathrm{pc}} \approx 1$ (Table 1$)$.

(ii) C vs. $v^{1 / 2}$ curve follows straight line (Fig. 5).

Table 1. Voltammetric data of the compound $\left(10^{-3} \mathrm{~mol} / \mathrm{L}\right)$ in supporting electrolyte $\left[\mathrm{Bu}_{4} \mathrm{~N}\right]$ $\left[\mathrm{BF}_{4}\right](0.1 \mathrm{~mol} / \mathrm{L})$ in $\mathrm{CH}_{2} \mathrm{Cl}_{2}$ at $25^{\circ} \mathrm{C}$.

\begin{tabular}{lcccccc}
\hline $\begin{array}{l}\text { Name of } \\
\text { compound }\end{array}$ & $\begin{array}{c}\text { Scan rate, } \\
v /(\mathrm{mV} / \mathrm{s})\end{array}$ & $\mathrm{E}_{\mathrm{pa}} /(\mathrm{mV})$ & $\mathrm{E}_{\mathrm{pc} /}(\mathrm{mV})$ & $\mathrm{I}_{\mathrm{pc}} / \mathrm{I}_{\mathrm{pa}}$ & $\Delta \mathrm{E}_{\mathrm{p}} /(\mathrm{mV})$ & $\mathrm{E}_{1 / 2} /(\mathrm{V})$ \\
\hline \multirow{5}{*}{ Ferrocene } & 25 & 580 & 665 & 0.99 & 85 & 0.53 \\
& 50 & 582 & 642 & 0.88 & 60 & 0.55 \\
& 75 & 582 & 660 & 0.95 & 78 & 0.54 \\
& 100 & 579 & 663 & 0.93 & 84 & 0.53 \\
Compound 1 & 125 & 583 & 665 & 1 & 82 & 0.54 \\
& 25 & 592 & 638 & 0.98 & 83 & 0.61 \\
& 50 & 580 & 660 & 0.88 & 83 & 0.62 \\
& 75 & 580 & 642 & 0.91 & 83 & 0.61 \\
& 100 & 582 & 656 & 0.89 & 120 & 0.61 \\
\hline
\end{tabular}

Fig. 5 also indicates that the redox behaviour is completely diffusion controlled and proceeds through Faradaic process. In Fig. 4, there is a post broader peak anodic peak appears at a slower scan rate at $800 \mathrm{mV}$. This observation is due to slow adsorption of the complex at the electrode surface at a slower scan rate.

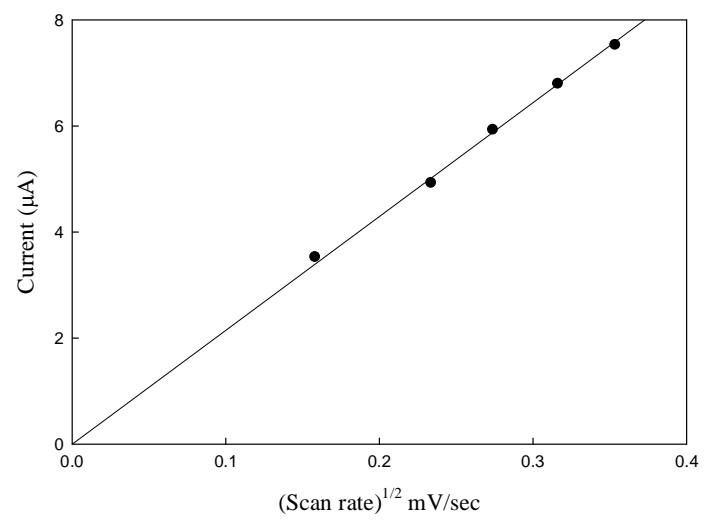

Fig. 5. (scan rate) ${ }^{1 / 2} v$ s. current for ferrocenyl-2,4-dinitrophenylhydrazone complex.

This post peak disappears and its anodic and cathodic potential are shifted with increasing scan rates. It may be due to adsorption rate decrease at a higher scan rate. The adsorption was further confirmed by chronocoulometric experiment and discuss in the next section. 
Compared to ferrocene, the redox potential of the compound is more anodic (Fig. 3). This is attributed to the attachment of electronic withdrawing dinitro-substituted aromatic core to the ferrocene (Lopez and Granell 1998).

Chronocoulometry: Double step chronocoulometry was performed in the absence and presence of air and shown in Fig. 6. The chronocoulometric experiment was performed to confirm whether the redox process of the complex is completely diffusion controlled or not.

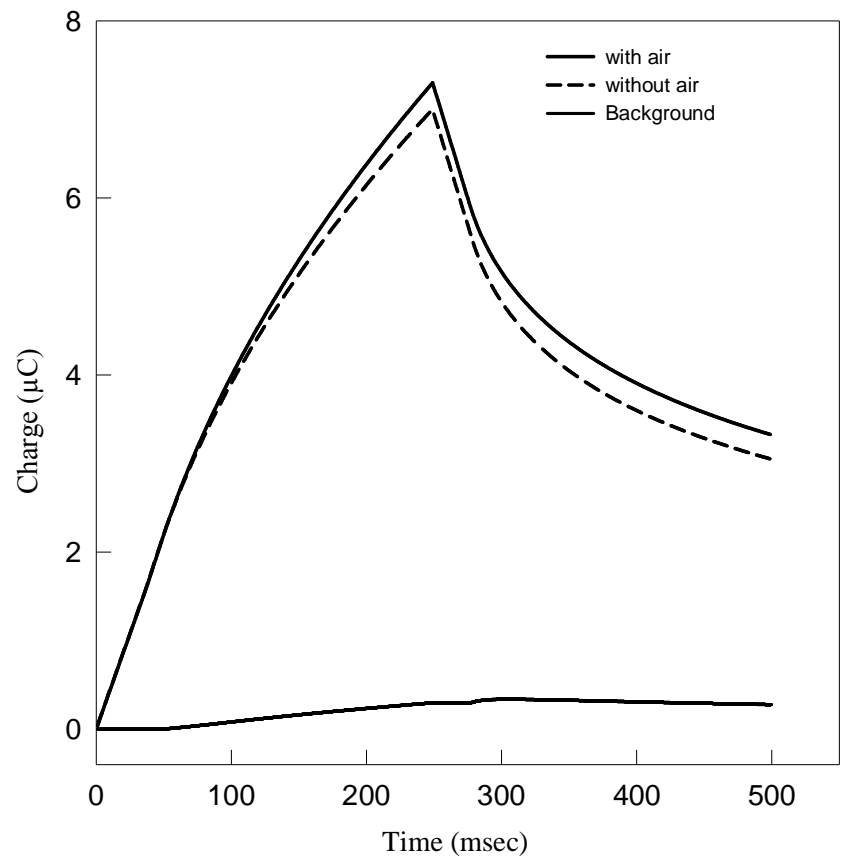

Fig. 6. Chronocoulometric curves of ferrocenyl-2, 4-dinitrophenylhydrazone in the absence and presence of air with background 0.1 M TBAP in dichloromethane.

The theory of the adsorption of chronocoulometry was recently developed (Bott and Hieneman. 2004, Baker et al. 1988). Later double potential step experiment was introduced by Anson and Osteryoung (1983) and theoretically characterized by Christie and associates (Christie 1967). According to the theory, the charge for the forward step is given by,

$$
\mathrm{Q}_{\text {forward }}=2 \mathrm{nFC}_{\mathrm{O}}^{\mathrm{b}}\left(\frac{\mathrm{D}_{\mathrm{O}} \mathrm{t}}{\pi}\right)^{1 / 2}+\mathrm{nFA} \Gamma_{0}+\mathrm{Q}_{\mathrm{dl}}
$$

And the charge for the reverse step $\mathrm{t}>\tau$ (transient time at which the reverse step starts) is given by equation (2). 


$$
\mathrm{Q}_{\text {reverse }}=2 \mathrm{nFC}_{\mathrm{O}}^{\mathrm{b}}\left(\frac{\mathrm{D}_{\mathrm{O}} \mathrm{t}}{\pi}\right)^{1 / 2} \times\left[\tau^{1 / 2}-(\mathrm{t}-\tau)^{1 / 2}\right]+\mathrm{Q}_{\mathrm{ads}}\left(\frac{2}{\pi} \sin ^{-1}\left(\frac{\tau}{\mathrm{t}}\right)^{1 / 2}\right)
$$

Fig. 7 has been constructed on the basis of equation (1) and (2). Charge for adsorption for the forward and reverse processes was found -1.267 and $1.205 \mu \mathrm{C}$, respectively calculated from the linear fit of the chronocoulometric data as shown in Fig. 7.

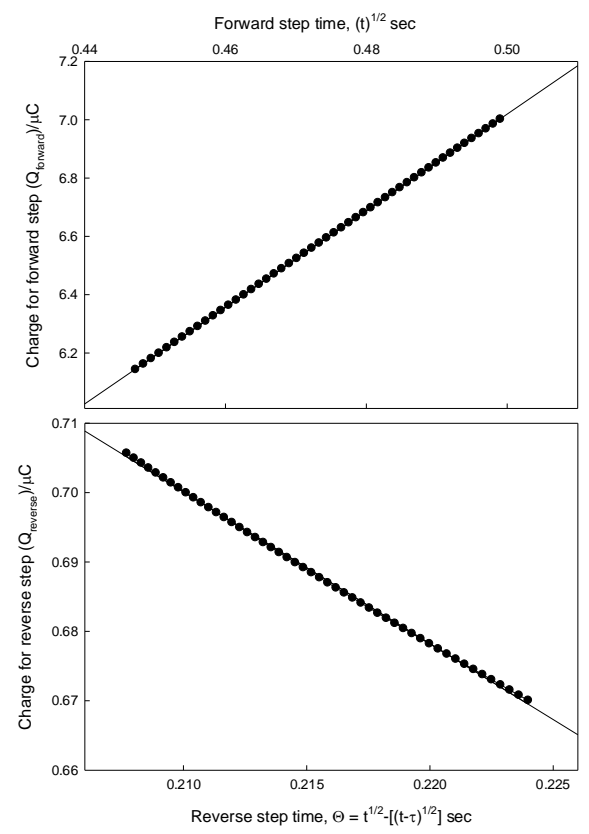

Fig. 7. Charge for the forward step $\left(\mathrm{Q}_{\mathrm{forward}}\right) v s$. forward step time $\left(\mathrm{t}^{1 / 2}\right)$ and charge for the reverse step $\left(\mathrm{Q}_{\text {reverse }}\right)$ vs. reverse step time $(\Theta)$ for the chronocoulometric response of the complex in $0.1 \mathrm{M}\left[\mathrm{Bu}_{4} \mathrm{~N}\right]\left[\mathrm{BF}_{4}\right]$ in dichloromethane. Step potential: 200 to 900 and 900 to $200 \mathrm{mV}$ vs. $\mathrm{Ag} / \mathrm{AgCl}$.

Thus, the net charge for the double potential step for the redox process is zero, which suggests that there is no adsorption (for either anodic or cathodic species) on the electrode surface. This result supports the previous cyclic voltammetric data and the redox process of the complex is totally diffusion controlled and governs by Faradaic process.

Enhanced redox reactivity of the complex in the presence of oxygen: The redox reactivity of the complex in the presence and absence of oxygen has been investigated by using differential pulse voltammetry and chronocoulometry. Accordingly, differential pulse voltammogram of the complex was performed in the presence and absence of oxygen, which was shown in Fig. 8. 


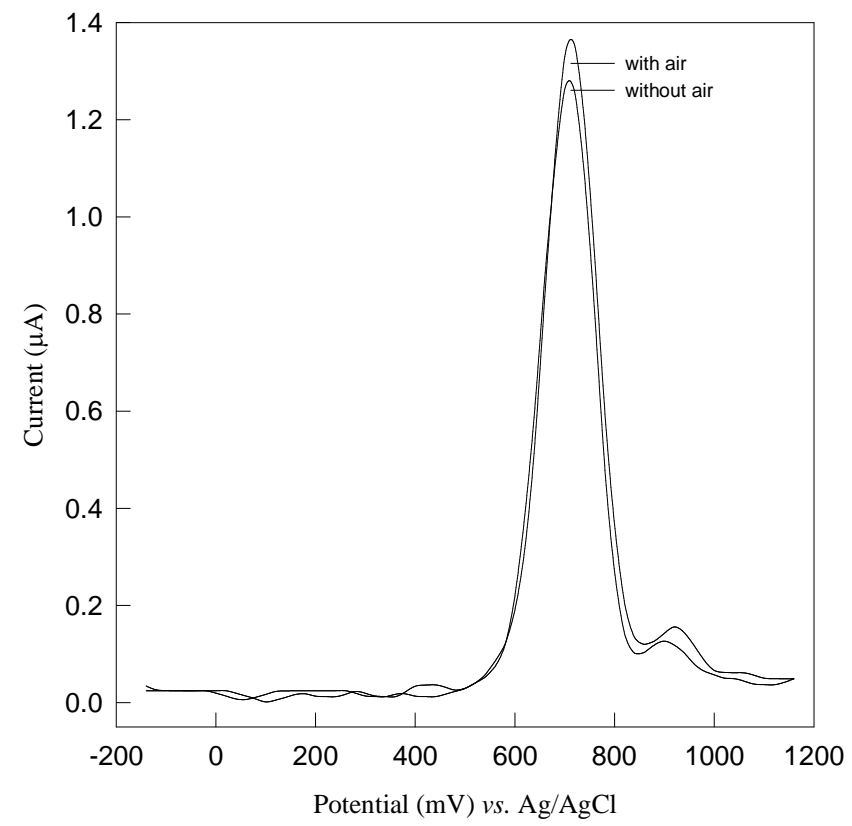

Fig. 8. Comparison of differential pulse voltammogram of ferrocenyl-2, 4 dinitrophenylhydrazone in the absence and presence of air.

The increased current in the voltammogram in the presence of oxygen clearly indicates that the redox process of the complex has been enhanced by oxygen.
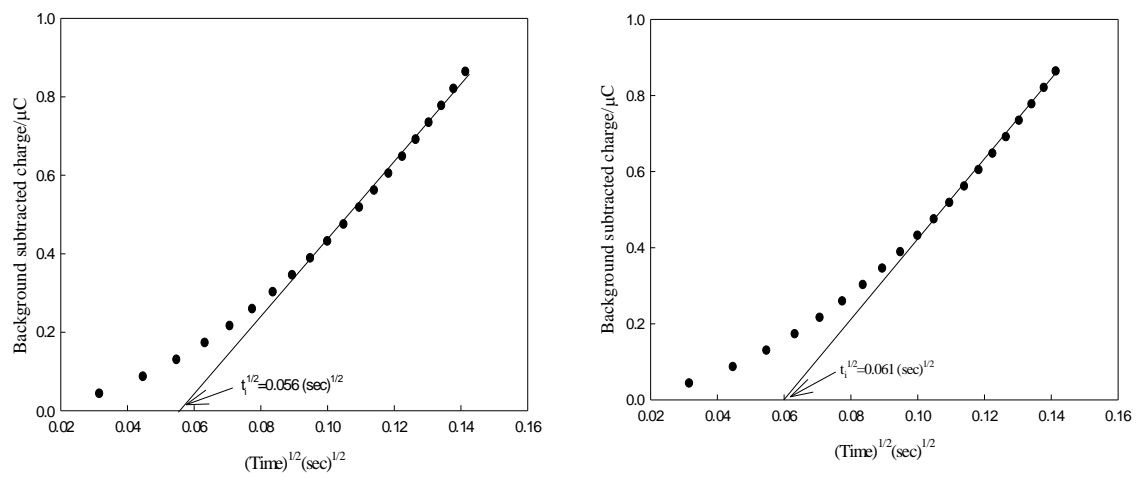

Fig. 9. Chronocoulometric kinetic plots of ferrocenyl-2,4-dinitrophenylhydrazone in the (A) absence and (B) presence of air.

The enhanced reactivity of the complex in the presence of oxygen has been further studied by chronocoulometry. Accordingly chronocoulometric kinetic plots (Christie et al. 1964) in the presence and absence of oxygen were constructed (Fig. 9A, B) from double potential step chronocoulometric data (Fig. 7). From chronocoulometric data, 
heterogeneous charge transfer rate constant $\left(k_{\mathrm{f}}\right)$ has been calculated by using the equations (3) and (4):

$$
k_{\mathrm{f}}=\frac{\text { slope } \times \mathrm{H} \times \pi^{1 / 2}}{2 \mathrm{nFAC} \mathrm{O}_{\mathrm{O}}^{0}}
$$

where, $H=\frac{\pi^{1 / 2}}{2 t_{i}^{1 / 2}}$

$\mathrm{t}_{\mathrm{i}}^{1 / 2}$ can be obtained by extrapolating the straight line obtained from the plot of background charge $v s . \mathrm{t}^{1 / 2}$. The heterogeneous charge transfer rate constants, $\left(k_{\mathrm{f}}\right)$ in the presence and absence of oxygen were found $5.73 \times 10^{-2} \mathrm{~cm} / \mathrm{sec}$ (Fig. 9A) and $5.63 \times 10^{-2}$ $\mathrm{cm} / \mathrm{sec}$ (Fig. 9B), respectively. From this data, it is confirmed that the redox behaviour of the complex is enhanced by oxygen.

Biological Studies: Ferrocene-based derivatives have a broad range of biological applications. The biological action of ferrocenes is related to their electron transfer rates and redox potentials. The antibacterial activity of the compound was tested against four bacterial strains: S. aureus, E. coli, Pseudomonas, Klebsiella. The compounds showed no significant activity against all the four bacterial strains. This may be attributed to the less lipophilic character of Schiff base and insolubility in water, which does not favour their permeation through the lipoid of microbial membranes (Bell et al. 2009).

Ferrocenyl-2,4-dinitrophenylhydrazone was synthesized and characterized using spectroscopic techniques. The redox properties of the complex were studied using cyclic voltammetry, differential pulse voltammetry and chronocoulometry. It was found that the redox process of the complex is completely diffusion controlled and governed by Faradaic process. The redox reactivity of the complex is enhanced in the presence of oxygen. Therefore, the complex could be a good candidate for the reduction of molecular oxygen.

\section{ACKNOWLEDGEMENTS}

The authors are grateful to the Department of Chemistry, University of Dhaka for electrochemical measurements and University Grants Commission (UGC) for financial support.

\section{REFERANCES}

Anson, F. C. and R. A. Osteryoung. 1983. Chronocoulometry: A convenient, rapid and reliable technique for detection and determination of adsorbed reactants. J. Chem. Edu. 60: 293-295.

Baker, R. T., Calabrese, J. C., Krusic, P. J., Therien, M. J. and W. C. Trogler. 1988. Spectroscopic, structural, electrochemical, and kinetic studies of ligand substitution in the 33e dinuclear radical $\mathrm{Fe}_{2}(\mathrm{CO})_{7}\left(. \mathrm{mu} . \mathrm{PPh}_{2}\right)$ and the $34 \mathrm{e}$ analogs $\left[\mathrm{Fe}_{2}(\mathrm{CO})_{7}\left(. \mathrm{mu} \mathrm{PPh}_{2}\right)\right]$-and $\mathrm{FeCo}(\mathrm{CO})_{7}$ (.mu. $\mathrm{PPh}_{2}$ ). J. Am. Chem. Soc. 110: 8392-8412. 
Batterjee, S. M., M. I. Marzouk, M. E. Aazab and M. A. El-Hashash. 2003. The electrochemistry of some ferrocene derivatives: redox potential and substituent effects. Appl. Organomet. Chem. 17: 291-297.

Bell, S. M., J. N. Pham and I. W. Carter. 2009. Antibiotic Susceptibility Testing by the CDS Method: A Manual for Medical and Veterinary Laboratories. $5^{\text {th }}$ Ed. The Antibiotic Reference Laboratory, Randwick, Australia.

Bott, A. W. and W. R. Heineman. 2004. Chronocoulometry. Current Separations 20: 121-126.

Chohan, Z. H. and C. T. Supuran. 2005. Organometallic compounds with biologically active molecules: in vitro antibacterial and antifungal activity of some 1,1'-(dicarbohydrazono) ferrocenes and their cobalt(II), copper(II), nickel(II) and zinc(II) complexes. Appl. Organomet. Chem. 19: 1207-1214.

Christie, J. H. 1967. The application of double potential-step chronocoulometry to the study of chemical reactions following the electrode reaction theory. J. Electroanal. Chem. 13: 79-89.

Christie, J. H., Lauer and R. A. Osteryoung. 1964. Integration of Single Sweep Oscillopolarograms: II . Comparison with Theory. J. Electrochem. Soc. 111: 1420-1423.

Elzaher, M. M., S. M. El-shiekh and M. Ewies. 2006. Biological studies of newly synthesized ferrocenyl complexes containing triazinone moiety. Appl. Organomet. Chem. 20: 597-602.

Elzaher, M. M., M. F. R. Fouda, R. A. Abdelsamaia and A. A. Labib. 2007. On the medicinal chemistry of ferrocene. Appl. Organomet. Chem. 21: 613-625.

Elzaher, M. M., and I. I. Ali. 2006. Preparation, characterization and biological studies of some novel ferrocenyl compounds. Appl. Organomet. Chem. 20: 107-111.

Errington, R. J. 1997. Advanced Practical Inorganic and Metalorganic Chemistry. Chapman and Hall, London, UK: pp. 94-98.

Lopez, C., R. Bosque, X Solans, and F. J. Bardia. 1997. Activation of $\sigma(\mathrm{C}-\mathrm{H})$ bonds in ferrocenylhydrazones derived from acetylferrocene. J. Organomet. Chem. 547: 309-317.

Lopez, C. and J. Granell. 1998. Influences of the electronic and steric effects of the substituents in cyclopalladation of ferrocenylhydrazones. J. Organomet. Chem. 555: 211-225.

Sarhan A. E.-W., Y. Nouchi and T. Izumi. 2003. Synthesis and electrochemical studies of ferrocene-dithiafulvalenes (Fc-DTF) and 1,1'-bis(dithiafulvalenyl)ferrocene (DTF-Fc-DTF). An approach towards new conducting organic materials. Tetrahedron 59: 6353-6362.

Trivedi, R., S. B. Deepthi, L. Giribabu, B. Sridhar, P. Sujitha, C. G. Kumar, and K. V. S. Ramakrishna. 2012. Synthesis, Crystral Structure, Electronic Spectroscopy, Electrochemistry and Biological Studies of Ferrocene-Carbohydrate Conjugates. Eur. J. Inorg. Chem. 22672277.

Xu, Y., C. Qiao, J. Li, S. Guo, X. Qi and Y. Fan. 2009. Synthesis, structural characterization and electrochemistry recognition of metal ions of two new ferrocenylhydrazone-based receptors. Appl. Organomet. Chem. 23: 421-424. 